\title{
Relationship between the Big Five personality traits and PTSD among French police officers
}

Liens entre les cinq grands facteurs de personnalité et le SSPT chez des policiers Français

Anaïs Madamet a, b, Catherine Potard ${ }^{\text {c, }}$, Isabelle Huart ${ }^{\text {a, b}}$, Wissam El-Hage ${ }^{\mathrm{d}}$, \& Robert

$$
\text { Courtois a, d }
$$

a c Université François-Rabelais de Tours, Département de psychologie, EA 2114

'Psychologie des âges de la vie, Tours, France, robert.courtois@univ-tours.fr ; isabelle.huart@univ-tours.fr

${ }^{\mathrm{b}}$ Centre Régional de Formation de la police Nationale, Tours, France

c Université d'Angers, Département de Psychologie, EA 4638 'Laboratoire de Psychologie des Pays de la Loire', Angers, France, catherine.potard@univ-angers.fr

${ }^{\mathrm{d}}$ CHRU de Tours, Clinique Psychiatrique Universitaire, Tours, France, wissam.elhage@univtours.fr

Correspondence concerning this article should be addressed to:

Robert Courtois

Université François Rabelais

Département de Psychologie, EA 2114,

3, rue des Tanneurs - BP 4103, F-37041 Tours Cedex 1

Tél. : +33 (0) 247366685

Fax: +33 (0) 247366484

Email: robert.courtois@univ-tours.fr

\section{Conflicts of interest: none}

Funding: This research did not receive any specific grant from funding agencies in the public, commercial, or not-for-profit sectors. 
Personality and PTSD symptoms in police

Relationship between the Big Five personality traits and PTSD among French police officers

Liens entre les cinq grands facteurs de personnalité et le TSPT chez des policiers Français

\section{Conflicts of interest: none}

Funding: This research did not receive any specific grant from funding agencies in the public, commercial, or not-for-profit sectors. 


\begin{abstract}
Introduction: Post-traumatic stress disorder (PTSD) is rare among police officers, but the symptoms of PTSD are not. Personality traits can be a contributing factor of stress disorders. Based on the Big Five personality traits, three personality profiles can be identified: Resilient, Overcontrolled, and Undercontrolled. Resilient people are characterized by high emotional stability (low Neuroticism), high social skills and self-confidence. Overcontrollers have higher scores on Neuroticism and they tend to internalize their negative emotions.

Undercontrollers are characterized by low Conscientiousness (impulsivity), a tendency toward social withdrawal and low self-esteem.
\end{abstract}

Objective: The aim of this study was to examine the role of personality traits and profiles in the emergence of PTSD symptoms among French police officers.

Method: Participants were French national police officers $(N=100, \mathrm{M}=32.9$ years, $\mathrm{SD}=9.8$, 19-57) who completed the Posttraumatic Stress Disorder Checklist Scale (PCLS) and the Big Five Inventory (BFI).

Results: Results revealed the three expected personality profiles: Resilients $(n=31)$, Overcontrollers $(n=43)$ and Undercontrollers $(n=19)$. The Resilients presented with the fewest PTSD symptoms and the Undercontrollers with the most (particularly Reexperiencing). The latter also scored the highest on Neuroticism and the lowest on Extraversion and Agreeableness. Police officers with an Undercontrolled profile were also the oldest or those who had served the longest in the police force. Neuroticism and length of service were the two predictors of PTSD symptoms for Reexperiencing and Avoidance.

Conclusion: This study demonstrates the contribution of each personality trait and length of service to PTSD symptoms in French police officers.

Keywords: Posttraumatic stress symptoms; Big Five personality factors; Personality profile; Work-related stress; Police personnel. 
Personality and PTSD symptoms in police

\section{Résumé}

Introduction : Le trouble de stress post-traumatique (TSPT) est rare parmi les policiers, mais les symptômes ne le sont pas. Les traits de personnalité peuvent être un facteur médiateur des troubles liés au stress. Ils permettent habituellement d'identifier trois profils de personnalité : les « résilients » caractérisés par une forte stabilité émotionnelle, des compétences sociales et une confiance en soi élevées ; les « sur-contrôlés » qui ont des scores élevés de Névrosisme et une tendance à internaliser leurs émotions négatives et des « sous-contrôlés » avec un faible Caractère consciencieux (impulsivité), une tendance à l'isolement social et une faible estime de soi.

Objectif : L'objectif de cette étude était d'examiner le rôle de la personnalité dans l'apparition de symptômes du TSPT chez les policiers français.

Méthode : Les participants étaient des policiers français $(N=100, \mathrm{M}=32,9$ ans, $\mathrm{ET}=9,8,19$ 57) qui ont complété l'échelle de l'état de stress post-traumatique (PCLS) et l'inventaire des cinq grands facteurs de personnalité (BFI).

Résultats : Les résultats ont retrouvé les trois profils de personnalité attendus : « résilients » $(\mathrm{n}=31)$, « sur-contrôlés » $(\mathrm{n}=43)$ et « sous-contrôlés » $(\mathrm{n}=19)$. Les premiers présentaient le moins de symptômes de TSPT et les derniers le plus (en particulier la répétition ou intrusion). Ils avaient également les scores les plus élevés de Névrosisme et les plus bas d'Extraversion et d'Agréabilité. Ces policiers étaient aussi les plus âgés ou ceux qui avaient servi le plus longtemps dans la police. Le Névrosisme et la durée du service étaient les deux facteurs prédictifs des symptômes de TSPT pour la répétition et l'évitement.

Conclusion : Cette étude met en évidence la contribution de chaque trait de personnalité et durée de service pour les symptômes de TSPT chez les policiers français.

Mots-clés: Symptômes de stress post-traumatique ; Cinq grands facteurs de personnalité ; Profil de personnalité ; Stress lié au travail ; Police. 


\section{Personality and PTSD symptoms in police \\ Relationship between the Big Five personality traits and PTSD among French police officers}

\section{Introduction}

Several studies have shown that police work is particularly stressful (e.g. Aytac, 2015; Lau, Hem, Berg, Ekeberg, \& Torgersen, 2006). Stress is related both to critical events, which are rare, and to everyday working conditions and the way that police officers cope with the pressures they face. Exposure to critical events (sexual trauma and combat trauma) is more predictive of posttraumatic stress disorder (PTSD) than other trauma types (Habersaat, Geiger, Abdellaoui, \& Wolf, 2015; Jakob, Lamp, Rauch, Smith, \& Buchholz, 2017). About $4.5 \%$ to $9 \%$ of police officers may suffer from full PTSD (Berger et al., 2012; Maia et al., 2007), but nearly 15-16\% suffer from partial PTSD (Maia et al., 2007; Marmar et al., 2006). Work stressors and managing the job can cause other mood disorders in police officers, such as burnout (Kula, 2017; Lau et al., 2006), which are also underpinned by individual vulnerability factors (El Hage, Powell, \& Surguladze, 2009). Understanding the protective factors against developing PTSD symptoms or other stress-related disorders is a major public health priority, and yet there have been few studies on protective or aggravating factors (Ellrich \& Baier, 2015).

The Big Five personality model (Five-Factor Model or FFM) is the most consensual approach to personality assessment. It proposes five main dimensions of personality, broadly defined as Extraversion vs. Introversion, Agreeableness vs. Antagonism, Conscientiousness or Control vs. Impulsivity, Neuroticism vs. Emotional Stability, and Openness to New Experience/Intellect $v s$. Closed-mindedness (John, Naumann, \& Soto, 2008; John \& Srivastava, 1999). Extraverted people are outgoing, sociable with positive emotionality, talkative, energetic, assertive, and excitement seeking. Agreeable individuals promote 
prosocial and communal orientation toward others, they are cooperative, friendly, considerate or empathic, generous, trustful, and kind. Conscientious individuals facilitate goal-directed and planned behavior, they are work-oriented, responsible, attentive, careful, dependable, persistent, orderly, and impulse controlled. Neuroticism is associated with anxiety and instability. Neurotic individuals are moody, angry, easily frustrated, lacking in confidence, insecure in relationships, and sometimes anti-social. Individuals high in Openness are imaginative, curious, creative, complex and subtle, with artistic values, unusual ideas, and varied experiences. They are also quick to learn, clever, insightful, and independent-minded (Caspi, Roberts, \& Shiner, 2005; John et al., 2008).

To understand and prevent mood disorders among police officers, it is important to gain a deeper insight into personality traits that may be linked to PTSD symptoms. Police officers probably share common personality traits (Lau et al., 2006; Lorr \& Strack, 1994), although some authors doubt the idea of a single profile (Wagner, 2005). The personality profile of police officers is likely to be characterized by low scores on Neuroticism (i.e., emotionally secure), high scores on Extraversion (i.e., more assertive and self-confident), high scores on Conscientiousness (i.e., with a strong pattern of self-discipline or sense of control), and high scores on Agreeableness (i.e., friendly, sociable and gregarious) (e.g. Lau et al., 2006; Lorr \& Strack, 1994; Wearing \& Hart, 1996). This suggests the existence of a "Rescue Personality" of police officers and firefighters (Mitchell \& Bray, 1990). Similar results have been found with other personality assessment tools (e.g. Eysenck: highly extraverted, venturesome and impulsive, but conforming, Gudjonsson \& Adlam, 1983).

Obviously, personality factors could represent a mediating factor between environmental stressors and mental health. For instance, several studies highlighted the role of Neuroticism (low Emotional stability) in perceived stress levels and stress reactivity (e.g. Garbarino, Chiorri, \& Magnavita, 2014; Heinrichs et al., 2005; Jakšić, Brajković, Ivezić, 
Personality and PTSD symptoms in police

Topić, \& Jakovljević, 2012; Vollrath, 2001; Yuan et al., 2011). Neuroticism fosters the subjective experience of negative emotions of events. By contrast, Extraversion and Agreeableness are both related to more positive feelings, and better adaptation to stressful work (e.g. Garbarino et al., 2014; Jakšić et al., 2012; Skomorovsky, 2013).

Three personality profiles were described by Block (1971) using the Q-Sort Method for personality assessment: Resilients, Overcontrollers, and Undercontrollers. These profiles were consistent and stable over time. Various subsequent studies on children or adults found similar results. Subsequently, they were also found using the Big Five personality traits (e.g. Asendorpf, Borkenau, Ostendorf, \& Van Aken, 2001; Asendorpf \& van Aken, 1999; Boehm, Asendorpf, \& Avia, 2002; Robins, John, Caspi, Moffitt, \& Stouthamer-Loeber, 1996). Across studies, Resilients obtain the most favorable descriptions on all five scales (high emotional stability and high scores in the other four personality traits). They demonstrate high social skills and self-confidence. They do not have mental disorders, and they succeed academically and socially. Overcontrollers score higher on Neuroticism than Resilients, associated with high Agreeableness and low Extraversion. They share some of the features of Resilients, but tend to internalize their problems and negative emotions. Undercontrollers are characterized by low Conscientiousness (impulsivity) and low Agreeableness, with a tendency toward social withdrawal and low self-esteem. They tend to fail academically and socially and have more emotional and behavioral problems.

Personality traits can thus constitute protective factors against stress and mood disorders, or, on the contrary, they can increase susceptibility to psychic morbidity and anxiety disorders. The aim of this study was to examine the role of personality traits and profiles in the emergence of PTSD symptoms among police officers. We expected to observe that police officers with Resilient characteristics would show the fewest PTSD symptoms and those with features of Undercontrollers would show the most. 


\section{Material and methods}

\subsection{Participants and procedure}

Participants were recruited in a French national police training center. All the police officers who were contacted agreed to participate in the study. After they had been informed of the aims of the study, they gave their informed consent, and completed the paper self-report questionnaire anonymously. Clear and precise instructions were given, and the importance of giving honest answers was stressed. No incentive was provided. This study complies with the Code of Ethics of the World Medical Association (Declaration of Helsinki).

Our sample comprised 100 French national police officers $(\mathrm{M}=32.9$ years, $\mathrm{SD}=9.8$, 19-57), including 28 women (27.7\%); 58 (58\%) were patrolmen (gardiens de la paix) or judicial police officers (officiers de police judiciaire), 41 (41\%) were auxiliary police officers, and $1(1 \%)$ was a forensic technician (technicien de la police scientifique). Participants were selected consecutively for inclusion in our sample, in close contact with the police districts in the 'Centre-Val de Loire' Region (France). Average length of service in the police force was 10.9 years $(\mathrm{SD}=9.9,0-34), 12.2$ years $(\mathrm{SD}=9.2,0-34)$ for men and 7.7 years $(\mathrm{SD}=9.3,0$ 30) for women. The median was respectively 10.0, 12.0, and 2.5 years. Eight participants were excluded due to incomplete questionnaires.

\subsection{Instruments}

PCLS. The Posttraumatic Stress Disorder Checklist Scale (Ventureyra, Yao, Cottraux, Note, \& De Mey-Guillard, 2002; Weathers, Litz, Herman, Huska, \& Keane, 1993) is a brief and practical self-report assessment of the severity of PTSD-related symptoms of intrusion/reexperiencing, avoidance/numbing, and hyperarousal (DSM-IV symptom criteria) in the past month. The 17 items are rated on a 5-point scale (from 1 - not at all - to 5 - 
Personality and PTSD symptoms in police

extremely); total score is the sum of all 17 items. Participants report the level of distress experienced for each item. The total score can be divided into 3 sub-scores: reexperiencing (items 1-5), avoidance (items 6-12), and hyperarousal (items 13-17). Scores range from 17 to 85, with higher scores indicating greater severity of PTSD symptoms. A cutoff score of 44 has demonstrated high diagnostic accuracy for PTSD (.97), with good specificity (.87) and sensitivity (.94) (Ventureyra et al., 2002).

BFI. The Big Five Inventory (John, Donahue, \& Kentle, 1991; Plaisant, Srivastava, Mendelsohn, Debray, \& John, 2005) is a self-administered questionnaire containing 45 items for five dimensions: Extraversion, Agreeableness, Conscientiousness, Neuroticism and Openness to experience. Participants answer on a Likert scale ranging from 1 (strongly disagree) to 5 (strongly agree). The BFI has good psychometric properties.

\subsection{Data analysis}

Internal consistency of the dimensions of the Big Five Inventory, as assessed by Cronbach's alpha coefficient, was $>.70$. We conducted a k-means cluster analysis, which allocates each case to the cluster with the nearest center point. To compare clusters (personality prototypes), we used analysis of variance (ANOVA), with post hoc comparisons (Bonferroni test) to assess the differences between groups (group interactions). Next, we calculated Bravais Pearson's correlations to evaluate the relationship between PTSD symptoms and personality traits. Next, we conducted a multiple regression analysis to determine the relative weights of length of service and Big Five personality traits on the PTSD symptoms. Finally, Structural Equation Modeling (SEM) was performed using the maximum likelihood estimation. In this study, selected values were greater than 0.90 for the comparative fit index (CFI) and the Normed Fit Index (NFI), less than 0.08 for the root meansquare error of approximation (RMSEA), and less than 3 for the $\chi 2 / \mathrm{df}$ (Arbuckle \& Wothke, 
Personality and PTSD symptoms in police

2003; Byrne, 2010; Hu \& Bentler, 1999). An alpha level of less than 5\% was considered statistically significant. Statistical analyses were performed with Statistica ${ }^{\circledR}$ and AMOS ${ }^{\circledR}$.

\section{Results}

Descriptive statistics of PTSD symptoms and the BFI scores are provided in Table 1, including Cronbach's alpha coefficient. Based on the cut-off score of 44 on the PCLS, 3 police officers $(3.2 \%)$ had a very probable diagnosis of PTSD. Based on the broader cut-off score of 34 on the PCLS, 12 police officers (12.9\%) were affected by partial PTSD. Using a diagnostic approach based on DSM-IV criteria, with at least 1 item reported for Reexperiencing (with a score $\geq 3$ ), associated with three or more items for Avoidance, and at least 2 items for Hyperarousal, 4 police officers (4.3\%) met the criteria for PTSD diagnosis. These 4 police officers were male $(\mathrm{M}=37.5$ years, $\mathrm{SD}=8.5,27-47)$, had been working for a long time in the police $(\mathrm{M}=15.8$ years, $\mathrm{SD}=8.2,8-27)$, and had high PTSD total severity scores $(M=45.5, S D=6.3,39-54)$ (with high sub-scores for Reexperiencing $(M=14.0, S D=$ 3.9, 10-19), Avoidance $(\mathrm{M}=16.2, \mathrm{SD}=1.3,15-18)$, and Hyperarousal $(\mathrm{M}=15.2, \mathrm{SD}=5.3$, $11-23))$.

Please Insert Table 1 here

Next, we conducted a k-means cluster analysis, which divided the police officers into three clusters according to personality prototypes (Asendorpf et al., 2001; Block, 1971). BFI scores yielded the three expected personality types: Resilients, Overcontrollers and Undercontrollers (Figure 1). The Resilients had the most positive personality traits, with high scores on Extraversion, Agreeableness, Conscientiousness, and Openness, and low scores on Neuroticism (high emotional stability). The Overcontrollers had a similar but less positive 
profile, while the Undercontrollers had high scores on Neuroticism and low scores on Conscientiousness (impulsivity). The Resilients group $(n=31)$ comprised $58.1 \%$ men, young adults $(M=27.5$ years, $S D=7.9,20-57)$, with the shortest length of service in the police $(M=$ $5.2, \mathrm{SD}=6.5$ years, $2-30)$. The Overcontrollers group $(n=43)$ was composed predominantly of men $(81.4 \%)$, young adults $(M=33.0$ years, $S D=9.6,19-52)$, with longer service $(M=$ 10.9 years, $\mathrm{SD}=9.0,0-31)$. The Undercontrollers group $(n=19)$ was composed of $73.7 \%$ men, who were older $(\mathrm{M}=38.3$ years, $\mathrm{SD}=8.9,20-51)$ and had spent the longest time in the police $(\mathrm{M}=16.9$ years, $\mathrm{SD}=8.6,1-32)$.

Please Insert Figure 1 and Table 2 here

Between these three groups, differences in the BFI scores were significant for all traits (Table 2). Post hoc comparisons (Bonferroni test) were performed to assess the differences between groups (group interactions). Next, we compared PTSD symptoms according to personality profile (Figure 2). These symptoms were greater in the Undercontrollers than in the Resilients and Overcontrollers. All differences between groups are shown in Table 3, including Post hoc comparisons (Bonferroni test).

Please Insert Figure 2 and Table 3 here

Undercontrollers had higher scores on Neuroticism, and lower scores on Conscientiousness and Agreeableness than Resilients and Overcontrollers. They also had more symptoms of PTSD (Reexperiencing, Avoidance, and Hyperarousal) than the other personality profiles. They were the oldest police officers, or those who had worked the longest in the police. The correlation between age and length of service was high $(.97, p$ $<.001$ ). Therefore, we looked for links between PTSD symptoms (related to reexperiencing, 
Personality and PTSD symptoms in police

avoidance, or hyperarousal), length of service, and personality traits. Table 4 shows correlations between PTSD symptoms and length of service (respectively $.55, .41$ and $.26, p<$ $.001)$.

\section{Please Insert Table 4 here}

Next, we carried out a step-by-step multiple regression analysis to determine the relative weights of length of service, Extraversion, Agreeableness, Conscientiousness, Neuroticism and Openness on the PTSD symptoms, starting with Reexperiencing. They explained $42 \%$ of the variance $(p<.001)$, with length of service, which made up the first step, contributing $31 \%(p<.001)$, followed by Neuroticism bringing about $11 \%$ of additional variance $(p<.001)$. We carried out the same procedure for Avoidance. The same independent variables explained $28 \%$ of the variance $(p<.001)$, with Neuroticism accounting for $21 \%$ ( $p<$ $.001)$ and length of service $7 \%(p<.01)$. Finally, we carried out the same procedure for Hyperarousal. Only Neuroticism explained more than $18 \%$ of the variance $(p<.001)$. When we removed Neuroticism from the equation, Agreeableness emerged in part as a predictor for PTSD symptoms: for Reexperiencing, only length of service explained $30 \%$ of variance $(p<$ $.001)$; for Avoidance, Agreeableness brought $4 \%$ additional variance $(p<.05)$ to the $17 \%$ explained by length of service $(p<.005)$, and it was the only predictor for Hyperarousal, but explaining only $8 \%$ of the variance $(p<.005)$.

We summarized these relations using a structural equation model (SEM). SEM provides a parsimonious and logical explanation of observed relationships for the measured variables. Relationships are shown in Figure 3. 


\section{Discussion}

The aim of our study was to identify which personality traits, and particularly which personality profile, were most likely to be associated with PTSD or PTSD symptoms. The results confirmed the three expected personality profiles: Resilients, Overcontrollers, and Undercontrollers. The Resilient group comprised 31 police officers, the Overcontrollers group 43, and the Undercontrollers group 19. The Resilients had the fewest PTSD symptoms and the Undercontrollers the most (particularly for Reexperiencing). Specifically, the Undercontrollers had the highest Neuroticism scores and the lowest Extraversion and Agreeableness scores (i.e. the most vulnerable personality profile). They were also the oldest or those who had served longest in the police. Correlational analysis showed that both length of service and personality traits were associated with PTSD symptoms. Neuroticism and length of service were the two predictors of Reexperiencing and Avoidance. While Agreeableness and Extraversion had negative correlations with PTSD symptoms (i.e., both, but particularly Agreeableness, are protective traits or associated with an absence of disorders), they were no longer significant when the police officers had high scores on Neuroticism.

Our results for personality profiles are in line with those in the literature. Resilients are more resistant to job stressors and do the best job (Garbarino et al., 2014; Jakšić et al., 2012; Lau et al., 2006). Personality traits can moderate perceived stress levels. The proportion of police officers in our sample with full PTSD was relatively low compared to the findings of other authors (Maia et al., 2007; Marmar et al., 2006), but participants were not part of an elite unit and they had not experienced a traumatic event such as 9/11 in New York. In France, in general, little consideration is given to the traumatic events that occur during police 
work. Officers rarely benefit from debriefing with structured psychological support. On the whole, they do not talk about any distress they may have suffered, and their supervisors also tend to ignore it. Older police officers in the lowest ranks are often those with the lowest education level and the least training. Consequently, if these police officers remain isolated, they are more at risk of developing psychic morbidity. With increasing length of service, police officers accumulate experiences of violent situations or the distress of others. They are more vulnerable to the negative effects of acute or chronic stress. Stress can be caused both by critical events and by daily stressors. Older police officers report more job pressure and fewer work injuries (Berg, Hem, Lau, Håseth, \& Ekeberg, 2005). The protective role of personality traits changes over time. Personality traits tend to change in a stressful environment and to be more associated with anxiety and psychological distress. This may call into question the idea that young police officers are inevitably more prone to post-trauma reactions (Hodgins, Creamer, \& Bell, 2001). It also suggests that police officers should be selected on personality criteria in order to ensure their capacity to adapt to their work and to cope with the stress that it involves.

The main limitations of this study are the size of the sample, the fact that participants were still in training, and the use of self-administered questionnaires. The results should be interpreted with caution, even though the participants were from a regional training center for all categories of police officers.

This study highlights the role of personality and length of service in coping with stress and in the occurrence of PTSD symptoms in French police officers, and particularly the role of neuroticism (low emotional stability). It suggests the relevance of screening young recruits, giving precedence to those presenting with personality traits that could have a protective role (high Extraversion, high Agreeableness, high Conscientiousness or low impulsivity). It is important to recognize the stress experienced by police officers in their work and to develop 
Personality and PTSD symptoms in police

strategies to help them cope with it throughout their career (Pole, Kulkarni, Bernstein, \& Kaufmann, 2006), such as developing social relationships and promoting peer support during and after stressful situations (Bowling, Eschleman, \& Wang, 2010). More specific support should also be given to police officers who show the characteristics of Undercontrollers because of their greater risk of developing PTSD symptoms. In sum, this research work should be replicated with a larger sample in order to gain a clearer view of the issue and perhaps to adapt actions to promote resilient functioning in a population that is often subject to post-traumatic stress.

Acknowledgment.

We would like to thank the Regional Training Center of police officers.

\section{Conflicts of interest: none}

Funding: This research did not receive any specific grant from funding agencies in the public, commercial, or not-for-profit sectors. 


\section{References}

Arbuckle, J. L., \& Wothke, W. (2003). AMOS (Version 5.0)[Computer software]. Chicago, IL, US: SmallWaters Corporation.

Asendorpf, J. B., Borkenau, P., Ostendorf, F., \& Van Aken, M. A. G. (2001). Carving personality description at its joints: Confirmation of three replicable personality prototypes for both children and adults. European Journal of Personality, 15(3), 169-198. doi:10.1002/per.408

Asendorpf, J. B., \& van Aken, M. A. G. (1999). Resilient, overcontrolled, and undercontroleed personality prototypes in childhood: Replicability, predictive power, and the trait-type issue. Journal of Personality and Social Psychology, 77(4), 815-832. doi:10.1037/00223514.77.4.815

Aytac, S. (2015). The sources of stress, the symptoms of stress and anger styles as a psychosocial risk at occupational health and safety: A case study on turkish police officers. Procedia Manufacturing, 3, 6421-6428. doi:10.1016/j.promfg.2015.07.915

Berg, A. M., Hem, E., Lau, B., Håseth, K., \& Ekeberg, Ø. (2005). Stress in the Norwegian police service. Occupational Medicine, 55(2), 113-120. doi:10.1093/occmed/kqi023

Berger, W., Coutinho, E. S. F., Figueira, I., Marques-Portella, C., Luz, M. P., Neylan, T. C., . . Mendlowicz, M. V. (2012). Rescuers at risk: A systematic review and meta-regression analysis of the worldwide current prevalence and correlates of PTSD in rescue workers. Social Psychiatry and Psychiatric Epidemiology, 47(6), 1001-1011. doi:10.1007/s00127-011-0408-2

Block, J. (1971). Lives through time. Berkeley, CA: Bancroft.

Boehm, B., Asendorpf, J. B., \& Avia, M. D. (2002). Replicable types and subtypes of personality: Spanish NEO-PI samples. European Journal of Personality, 16(S1), S25-S41. doi:10.1002/per.450

Bowling, N. A., Eschleman, K. J., \& Wang, Q. (2010). A meta-analytic examination of the relationship between job satisfaction and subjective well-being. Journal of Occupational and Organizational Psychology, 83(4), 915-934. doi:10.1348/096317909X478557

Byrne, B. M. (2010). Structural Equation Modeling with AMOS: Basic concepts, Applications, and Programming (2 ed.). New York, NY, US: Routledge.

Caspi, A., Roberts, B. W., \& Shiner, R. L. (2005). Personality development: stability and change. Annual Review of Psychology, 56, 453-484. doi:10.1146/annurev.psych.55.090902.141913

El Hage, W., Powell, J. F., \& Surguladze, S. A. (2009). Vulnerability to depression: What is the role of stress genes in gene $\times$ environment interaction? Psychological Medicine, 39(9), 1407-1411. doi:10.1017/S0033291709005236

Ellrich, K., \& Baier, D. (2015). Post-traumatic stress symptoms in police officers following violent assaults. Journal of Interpersonal Violence, 32(3), 331-356. doi:10.1177/0886260515586358

Garbarino, S., Chiorri, C., \& Magnavita, N. (2014). Personality traits of the five-factor model are associated with work-related stress in special force police officers. International Archives of Occupational and Environmental Health, 87(3), 295-306. doi:10.1007/s00420-013-0861-1

Gudjonsson, G. H., \& Adlam, K. R. C. (1983). Personality patterns of British police officers. Personality and Individual Differences, 4(5), 507-512. doi:10.1016/0191-8869(83)90081-8

Habersaat, S. A., Geiger, A. M., Abdellaoui, S., \& Wolf, J. M. (2015). Health in police officers: Role of risk factor clusters and police divisions. Social Science and Medicine, 143(Supplement C), 213222. doi:10.1016/j.socscimed.2015.08.043

Heinrichs, M., Wagner, D., Schoch, W., Soravia, L. M., Hellhammer, D. H., \& Ehlert, U. (2005). Predicting posttraumatic stress symptoms from pretraumatic risk factors: A 2-year prospective follow-up study in firefighters. The American journal of psychiatry, 162(12), 2276-2286.

Hodgins, G., Creamer, M., \& Bell, R. (2001). Risk factors for posttrauma reactions in police officers: A longitudinal study. The Journal of Nervous and Mental Disease, 189(8), 541-547. 
Hu, L., \& Bentler, P. M. (1999). Cutoff criteria for fit indexes in covariance structure analysis: Conventional criteria versus new alternatives. Structural Equation Modeling: A Multidisciplinary Journal, 6(1), 1-55. doi:10.1080/10705519909540118

Jakob, J. M. D., Lamp, K., Rauch, S. A. M., Smith, E. R., \& Buchholz, K. R. (2017). The impact of trauma type or number of traumatic events on ptsd diagnosis and symptom severity in treatment seeking veterans. The Journal of Nervous and Mental Disease, 205(2), 83-86. doi:10.1097/nmd.0000000000000581

Jakšić, N., Brajković, L., Ivezić, E., Topić, R., \& Jakovljević, M. (2012). The role of personality traits in posttraumatic stress disorder (PTSD). Psychiatria Danubina, 24(3.), 256-266.

John, O. P., Donahue, E. M., \& Kentle, R. L. (1991). The Big Five Inventory--Versions $4 a$ and 54. Retrieved from Berkeley, CA, US:

John, O. P., Naumann, L. P., \& Soto, C. J. (2008). Paradigm shift to the integrative big-five trait taxonomy: History, measurement, and conceptual issues. In O. P. John, R. W. Robins, \& L. A. Pervin (Eds.), Handbook of personality: Theory and research (3 ed., pp. 114-158). New York, NY, US: Guilford Press.

John, O. P., \& Srivastava, S. (1999). The big five trait taxonomy: History, measurement, and theoretical perspectives. In L. A. Pervin \& O. P. John (Eds.), Handbook of personality: theory and research (2 ed., pp. 102-138). New York, NY, US: Guilford Press.

Kula, S. (2017). Occupational stress, supervisor support, job satisfaction, and work-related burnout: Perceptions of Turkish National Police (TNP) members. Police Practice and Research, 18(2), 146-159. doi:10.1080/15614263.2016.1250630

Lau, B., Hem, E., Berg, A. M., Ekeberg, Ø., \& Torgersen, S. (2006). Personality types, coping, and stress in the Norwegian police service. Personality and Individual Differences, 41(5), 971-982. doi:10.1016/j.paid.2006.04.006

Lorr, M., \& Strack, S. (1994). Personality profiles of police candidates. Journal of Clinical Psychology, 50(2), 200-207. doi:10.1002/1097-4679(199403)50:2<200::AID-JCLP2270500208>3.0.CO;2-1

Maia, D. B., Marmar, C. R., Metzler, T., Nóbrega, A., Berger, W., Mendlowicz, M. V., . . Figueira, I. (2007). Post-traumatic stress symptoms in an elite unit of Brazilian police officers: Prevalence and impact on psychosocial functioning and on physical and mental health. Journal of Affective Disorders, 97(1), 241-245. doi:10.1016/j.jad.2006.06.004

Marmar, C. R., McCaslin, S. E., Metzler, T. J., Best, S., Weiss, D. S., Fagan, J., . . Neylan, T. (2006). Predictors of Posttraumatic Stress in Police and Other First Responders. Annals of the New York Academy of Sciences, 1071(1), 1-18. doi:10.1196/annals.1364.001

Mitchell, J. T., \& Bray, G. (1990). Emergency services stress: Guidelines for preserving the health and careers of emergency services personnel. Englewood Cliffs, NJ, US: Prentice Hall.

Plaisant, O., Srivastava, S., Mendelsohn, G. A., Debray, A., \& John, O. P. (2005). Relations entre le Big Five Inventory français et le manuel diagnostique des troubles mentaux dans un échantillon clinique français [Relations between the French version of the Big Five Inventory and the DSM classification in a French clinical sample of psychiatric disorders]. Annales Médicopsychologiques, revue psychiatrique, 163(2), 161-167. doi:10.1016/j.amp.2005.02.002

Pole, N., Kulkarni, M., Bernstein, A., \& Kaufmann, G. (2006). Resilience in Retired Police Officers. Traumatology, 12(3), 207-216. doi:10.1177/1534765606294993

Robins, R. W., John, O. P., Caspi, A., Moffitt, T. E., \& Stouthamer-Loeber, M. (1996). Resilient, overcontrolled, and undercontrolled boys: Three replicable personality types. Journal of Personality and Social Psychology, 70(1), 157-171. doi:10.1037/0022-3514.70.1.157

Skomorovsky, A. (2013). Psychological well-being of Canadian forces officer candidates: The role of personality and coping strategies. Military Psychology, 25(1), 3-12. doi:10.1037/h0094752

Ventureyra, V. A. G., Yao, S. N., Cottraux, J., Note, I., \& De Mey-Guillard, C. (2002). The validation of the Posttraumatic Stress Disorder Checklist Scale in posttraumatic stress disorder and nonclinical subjects. Psychotherapy and Psychosomatics, 71(1), 47-53. doi:10.1159/000049343 
Personality and PTSD symptoms in police

Vollrath, M. (2001). Personality and stress. Scandinavian Journal of Psychology, 42(4), 335-347. doi:10.1111/1467-9450.00245

Wagner, S. L. (2005). The "Rescue Personality": Fact or fiction? Australasian Journal of Trauma and Disaster Studies, 2(2005-2).

Wearing, D. A. J., \& Hart, P. M. (1996). Work and non-work coping strategies: their relation to personality, appraisal and life domain. Stress Medicine, 12(2), 93-103. doi:10.1002/(SICI)1099-1700(199604)12:2<93::AID-SMI694>3.0.CO;2-X

Weathers, F. W., Litz, B. T., Herman, D. S., Huska, J. A., \& Keane, T. M. (1993). The PTSD Checklist $(P C L)$ : Reliability, validity, and diagnostic utility. Paper presented at the annual convention of the international society for traumatic stress studies, San Antonio, TX.

Yuan, C., Wang, Z., Inslicht, S. S., McCaslin, S. E., Metzler, T. J., Henn-Haase, C., . . Marmar, C. R. (2011). Protective factors for posttraumatic stress disorder symptoms in a prospective study of police officers. Psychiatry Research, 188(1), 45-50. doi:10.1016/j.psychres.2010.10.034 
Personality and PTSD symptoms in police

Figure 1. Resilient, overcontrolled and undercontrolled personality profiles.

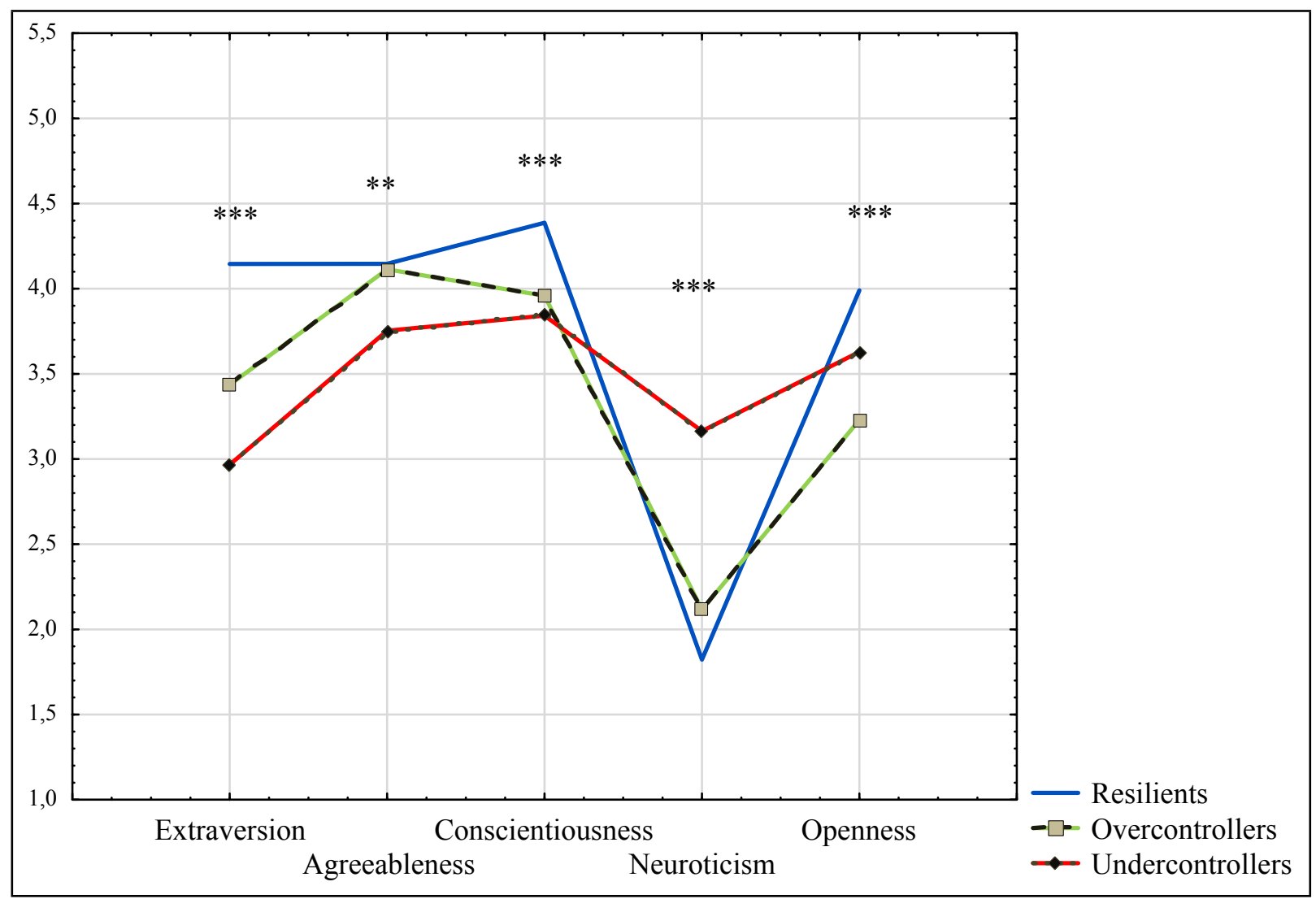

$*: p<.05 ; * *: p<.01$ and $* * *: p<.001$ 
Figure 2. PTSD symptoms (means and standard deviations) according to personality profiles (Resilient, overcontrolled and undercontrolled).

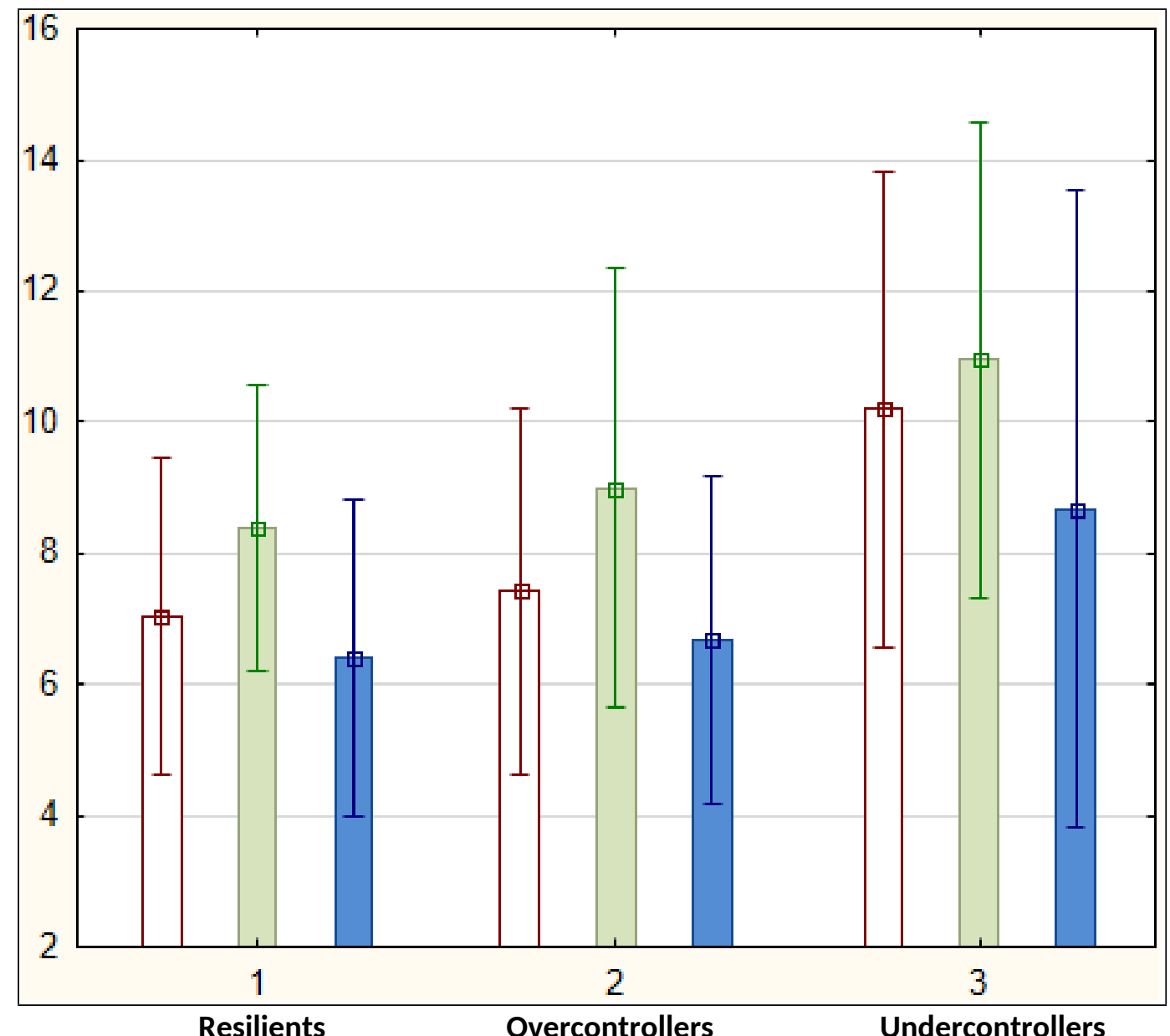

Reexperience symptoms

Avoidance symptoms

回

Hyperarousal symptoms 
Figure 3. Impact of personality traits and length of service on PTSD symptoms.

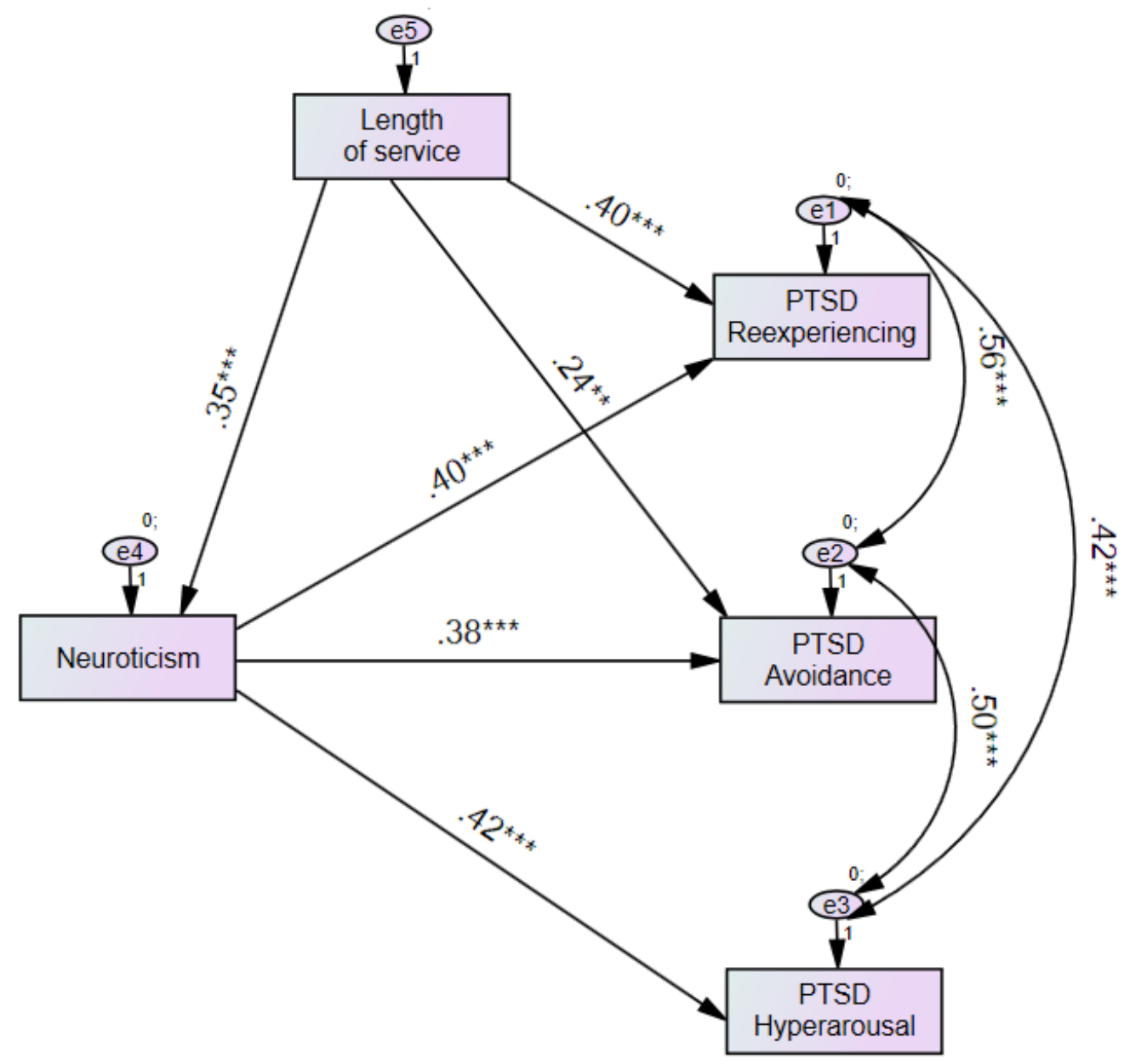

$*: p<.05 ; * *: p<.01 ; * * *: p<.001$

$\chi 2=1.60, \mathrm{df}=1$

$\chi 2 / \mathrm{df}=.87$

$p<.21$

$\mathrm{CFI}=99.6$

$\mathrm{NFI}=99.1$

RMSEA $=.077$ 
Personality and PTSD symptoms in police

Table 1. Descriptive statistics of PTSD symptoms and personality traits.

\begin{tabular}{lcccccccc}
\hline & $\begin{array}{c}\text { Mean } \\
{[\text { CI 95\%] }}\end{array}$ & Median Minimum Maximum & Q1 & Q3 & SD $\begin{array}{c}\text { Cronbach's } \\
\text { coefficient }\end{array}$ \\
\hline PCLS & & & & & & & & \\
Reexperiencing score & $7.9[7.2-8.5]$ & 7 & 5 & 19 & 5 & 10 & 3.1 & .76 \\
Avoidance score & $9.2[8.5-9.8]$ & 8 & 7 & 24 & 7 & 10 & 3.2 & .69 \\
Hyperarousal score & $7.0[6.4-7.7]$ & 5 & 5 & 23 & 5 & 8 & 3.2 & .85 \\
Total score & $24.1[22.4-25.7]$ & 21 & 17 & 54 & 18 & 27 & 8.1 & .88 \\
BFI & & & & & & & & \\
Extraversion & $3.6[3.4-3.7]$ & 3.6 & 1.9 & 4.9 & 3.1 & 4.0 & .7 & .84 \\
Agreeableness & $4.0[4.0-4.1]$ & 4.1 & 2.9 & 5.0 & 3.8 & 4.3 & .4 & .75 \\
Conscientiousness & $4.1[4.0-4.2]$ & 4.1 & 2.4 & 5.0 & 3.8 & 4.3 & .5 & .80 \\
Neuroticism & $2.2[2.1-2.4]$ & 2.1 & 1.1 & 4.4 & 1.7 & 2.6 & .7 & .83 \\
Openness & $3.6[3.4-3.7]$ & 3.5 & 2.2 & 4.8 & 3.2 & 4.0 & .5 & .80 \\
\hline
\end{tabular}

BFI: Big Five Inventory; PCLS: Posttraumatic Stress Disorder Checklist Scale; CI:

Confidence interval; Q1: $1^{\text {st }}$ Quartile; Q3: $3^{\text {rd }}$ Quartile 
Personality and PTSD symptoms in police

Table 2. Resilient, overcontrolled and undercontrolled personality profiles (means, standard deviations and inter-group comparisons)

\begin{tabular}{|c|c|c|c|c|c|c|}
\hline & $\begin{array}{l}\text { Resilients } \\
\text { (Cl.1) }\end{array}$ & $\begin{array}{l}\text { Overcontrollers } \\
(\mathrm{Cl} .2)\end{array}$ & $\begin{array}{c}\text { Undercontrollers } \\
(\text { Cl. 3) }\end{array}$ & $\mathrm{F}$ & $p$ & $\begin{array}{l}\text { Bonferroni } \\
\text { post-hoc test }\end{array}$ \\
\hline Extraversion & $4.14(.44)$ & $3.28(.51)$ & $3.47(.76)$ & & $* * *$ & $\begin{array}{l}\mathrm{Cl} .3>\mathrm{Cl} .1 * * \\
\mathrm{Cl} .3>\mathrm{Cl} .2(\mathrm{~ns}) \\
\text { Cl. } 2>\mathrm{Cl} .1 * * *\end{array}$ \\
\hline Agreeableness & $4.20(.40)$ & $4.08(.33)$ & $3.41(.29)$ & 6.53 & $* *$ & $\begin{array}{l}\text { Cl. } 3>\mathrm{Cl} .1 * * * \\
\text { Cl. } 3>\mathrm{Cl} .2^{* * *} \\
\text { Cl. } 2>\mathrm{Cl} .1(\mathrm{~ns})\end{array}$ \\
\hline Conscientiousness & $4.43(.31)$ & $3.93(.43)$ & $3.77(.60)$ & & $* * *$ & $\begin{array}{l}\text { Cl. } 3>\mathrm{Cl} .1 * * * \\
\text { Cl. } 3>\mathrm{Cl} .2 \text { (ns) } \\
\text { Cl. } 2>\mathrm{Cl} .1 * * *\end{array}$ \\
\hline Neuroticism & $1.71(.43)$ & $2.31(.42)$ & $3.45(.61)$ & & $* * *$ & $\begin{array}{l}\text { Cl. } 3>\mathrm{Cl} .1 * * * \\
\text { Cl. } 3>\mathrm{Cl} .2 * * * \\
\text { Cl. } 2>\mathrm{Cl} .1 * * *\end{array}$ \\
\hline Openness & $3.80(.52)$ & $3.33(.42)$ & $3.88(.67)$ & & $* * *$ & $\begin{array}{l}\text { Cl. } 3>\mathrm{Cl} .1 \text { (ns) } \\
\text { Cl. } 3>\mathrm{Cl} .2 * * \\
\text { Cl. } 2>\mathrm{Cl} .1 * * *\end{array}$ \\
\hline
\end{tabular}

$*: p<.05 ; * *: p<.01$ and $* * *: p<.001$ 
Personality and PTSD symptoms in police

Table 3. PTSD symptom clusters (means, standard deviations and inter-group comparisons) in the three personality prototypes

\begin{tabular}{|c|c|c|c|c|c|c|}
\hline & $\begin{array}{l}\text { Resilients } \\
\text { (Cl.1) }\end{array}$ & $\begin{array}{c}\text { Overcontrollers } \\
(\mathrm{Cl} .2)\end{array}$ & $\begin{array}{l}\text { Undercontrollers } \\
(\mathrm{Cl} .3)\end{array}$ & $\mathrm{F}$ & $p$ & $\begin{array}{c}\text { Bonferroni } \\
\text { post-hoc test }\end{array}$ \\
\hline Reexperiencing & $7.03(2.42)$ & $7.41(2.79)$ & $10.21(3.63)$ & & $* * *$ & $\begin{array}{l}\mathrm{Cl} .3>\mathrm{Cl} .1 * * * \\
\mathrm{Cl} .3>\mathrm{Cl} .2 * * \\
\mathrm{Cl} .2>\mathrm{Cl} .1(\mathrm{~ns})\end{array}$ \\
\hline Avoidance & $8.39(2.17)$ & $9.00(3.39)$ & $10.95(3.64)$ & 4.26 & $*$ & $\begin{array}{l}\mathrm{Cl} .3>\mathrm{Cl} .1 * \\
\mathrm{Cl} .3>\mathrm{Cl} .2(\mathrm{~ns}) \\
\mathrm{Cl} .2>\mathrm{Cl} .1(\mathrm{~ns})\end{array}$ \\
\hline Hyperarousal & $6.42(2.42)$ & $6.70(2.49)$ & $8.68(4.84)$ & 3.58 & $*$ & $\begin{array}{l}\mathrm{Cl} .3>\mathrm{Cl} .1 * \\
\mathrm{Cl} .3>\mathrm{Cl} .2(\mathrm{~ns}) \\
\mathrm{Cl} .2>\mathrm{Cl} .1(\mathrm{~ns})\end{array}$ \\
\hline
\end{tabular}


Personality and PTSD symptoms in police

Table 4. Correlations between Big Five personality traits and PTSD symptoms.

\begin{tabular}{|c|c|c|c|c|c|c|c|c|}
\hline & \multicolumn{5}{|c|}{ BFI personality traits } & \multicolumn{3}{|c|}{ PTSD clusters } \\
\hline & $\mathrm{E}$ & A & $\mathrm{C}$ & $\mathrm{N}$ & $\mathrm{O}$ & Reexperience & Avoidance & Hyperarousal \\
\hline Length of service & $-.36 * * *$ & $-.26^{*}$ & $-.22 *$ & $.34 * * *$ & -.03 & $.55^{* * *}$ & $.41 * * *$ & $.26^{*}$ \\
\hline Extraversion & 1 & .11 & $.26^{*}$ & $-.31 * *$ & .15 & -.20 & $-.27 * *$ & -.20 \\
\hline Agreeableness & & 1 & $.30 * *$ & $-.36 * * *$ & -.05 & $-.22 *$ & $-.31 * *$ & $-.29 * *$ \\
\hline Conscientiousness & & & 1 & $-.34 * * *$ & $.34 * *$ & -.08 & -.15 & -.19 \\
\hline Neuroticism & & & & 1 & -.02 & $.50 * * *$ & $.46^{* * *}$ & $.43 * * *$ \\
\hline Openness & & & & & 1 & .13 & .09 & .07 \\
\hline Reexperience & & & & & & 1 & $.70 * * *$ & $* * *$ \\
\hline Avoidance & & & & & & & 1 & $.61 * * *$ \\
\hline Hyperarousal & & & & & & & & 1 \\
\hline
\end{tabular}

E: Extraversion; A: Agreeableness; C: Conscientiousness; N: Neuroticism; O: Openness; *: $p<.05 ; * *: p<.01$; ***: $p<.001$ 